\title{
NY-ESO-1 Positive Tumor Cells Present
}

National Cancer Institute

\section{Source}

National Cancer Institute. NY-ESO-1 Positive Tumor Cells Present. NCI Thesaurus. Code C131557.

An indication that Cancer/T estis Antigen 1 expression has been detected in a sample. 